\title{
Determination of Optimum Pinch Point Temperature Difference Depending on Heat Source Temperature and Organic Fluid with Genetic Algorithm
}

\author{
${ }^{*}$ Sadik Ata, ${ }^{2}$ Ali Kahraman, ${ }^{3}$ Remzi Şahin \\ ${ }^{1}$ KTO Karatay University, Faculty of Engineering and Natural Sciences, Department of Mechanical Engineering, \\ sadik.ata@karatay.edu.tr, \\ ${ }^{2}$ Necmettin Erbakan University, Faculty of Engineering, Department of Mechanical Engineering, \\ akahraman@erbakan.edu.tr, \\ ${ }^{3}$ KTO Karatay University, Faculty of Engineering and Natural Sciences, Department of Mechanical Engineering, \\ remzi.sahin@karatay.edu.tr,
}

\begin{abstract}
In this study, the effect of evaporator pinch point temperature difference $\left(\Delta \mathrm{T}_{\mathrm{PP}, \mathrm{e}}\right)$ value in Organic Rankine Cycle (ORC) on system performance was determined. Under different applications of ORC, optimum $\Delta \mathrm{T}_{\mathrm{PP}, \mathrm{e}}$ value has been determined in ORC systems designed with different heat source temperatures. By changing the $\Delta \mathrm{T}_{\mathrm{PP}, \mathrm{e}} \mathrm{value}$, the heat input provided to the system, the mass flow of organic fluid, the evaporation pressure and the enthalpy drop in the turbine are affected. In thermodynamic optimization, the objective function is determined as turbine power maximization. Genetic algorithm optimization technique is used. Within the scope of low and high temperature $\mathrm{ORC}$ applications, the optimum $\Delta \mathrm{T}_{\mathrm{PP}, \mathrm{e}}$ value of different organic fluids under 10 different heat source temperatures (Low, 90-130 ${ }^{\circ} \mathrm{C}$; High, 250-290 ${ }^{\circ} \mathrm{C}$ ) has been determined. Low temperature organic fluids have been selected from dry, isentropic, wet and new-generation categories. High temperature organic fluids have been selected from the alkane, aromatic hydrocarbon, and siloxane categories. The effect of $\Delta \mathrm{T}_{\mathrm{PP}, \mathrm{e}}$ on fluids of different categories was determined for low and high temperature ORCs. It has been determined that taking the $\Delta \mathrm{T}_{\mathrm{PP}, \mathrm{e}}$ value constant regardless of the heat source temperature and organic fluid causes performance loss in ORC.
\end{abstract}

Keywords: Genetic Algorithm, Low-High Organic Fluids Optimum, Pinch Point, Organic Rankine Cycle, Thermodynamic Optimization

\section{INTRODUCTION}

The Organic Rankine Cycle (ORC) works like the Rankine cycle as its working principle, the difference is that an organic fluid other than water is used. The fluid used in ORC has a lower boiling point and a higher vapor pressure than water and can therefore be used in low temperature heat sources to generate electricity. The organic fluid is selected to best match the heat source according to its different thermodynamic properties, resulting in higher efficiency of both the process and the expander.

In this study, the performance of organic fluids was determined depending on the heat source temperature under low and high temperature applications of ORC. The optimum evaporator pinch point temperature difference $\left(\Delta \mathrm{T}_{\mathrm{PP}, \mathrm{e}}\right)$ was determined for each heat source temperature. $\Delta \mathrm{T}_{\mathrm{PP}, \mathrm{e}} ; \mathrm{It}$ is defined as the difference between the evaporator pinch point temperature $\left(\mathrm{T}_{\mathrm{P}, \mathrm{e}}\right)$ and the evaporation temperature of the organic fluid. It has been observed that this value $\left(\Delta \mathrm{T}_{\mathrm{PP}, \mathrm{e}}\right)$, which was taken as a constant in most of the previous studies, seriously affects the ORC performance. Important studies on this subject are summarized.

$\mathrm{Wu}$ et al. [1] conducted a study on the determination of $\Delta \mathrm{T}_{\mathrm{PP}, \mathrm{e}}$ and $\Delta \mathrm{T}_{\mathrm{PP}, \mathrm{c}}$ in ORC designed using mixing fluids. They considered exergo - economic performance, which is the ratio of annual total cost to net power, as an evaluation criterion. They stated that the increase of $\Delta \mathrm{T}_{\mathrm{PP}, \mathrm{e}}$ rapidly increased exergo economic performance, but reached the best performance at optimum $\Delta \mathrm{T}_{\mathrm{PP}, \mathrm{e}}$ value. They concluded that the optimum $\Delta \mathrm{T}_{\mathrm{PP}, \mathrm{e}}$ for mixing fluids should be between $3-6{ }^{\circ} \mathrm{C}$.

Yu et al. [2] developed a method that can instantly determine the organic fluid and working conditions in ORC depending on the $\Delta T_{\mathrm{PP}, \mathrm{e}}$. They defined the $\Delta \mathrm{T}_{\mathrm{PP}, \mathrm{e}}$ formed in the preheater and the $\Delta \mathrm{T}_{\mathrm{PP}, \mathrm{e}}$ formed in the evaporator for this aim. They determined that the maximum power is reached when there is a suitable difference between the heat source inlet temperature and the critical temperature of the fluid, and the fluid evaporates near the critical region.

\footnotetext{
* Corresponding Author
} 
Liu et al. [3] performed a performance analysis for geothermal different heat source temperatures in the ORC system they designed using R245fa. The effect of $\Delta \mathrm{T}_{\mathrm{PP}, \mathrm{e}}$ on system performance has been determined. Net power, turbine size parameter, volume flow rate and total thermal conductivity were calculated. It has been determined that $\Delta \mathrm{T}_{\mathrm{PP}, \mathrm{e}}$ is inversely proportional to total thermal conductivity and net power. It has been stated that the optimum $\Delta \mathrm{T}_{\mathrm{PP}, \mathrm{e}}$ is associated with the heat source inlet temperature, and low $\Delta T_{\mathrm{PP}, \mathrm{e}}$ provides high net power. As a result of the change of heat source inlet temperature between $80-180{ }^{\circ} \mathrm{C}$, it has been determined that $\Delta \mathrm{T}_{\mathrm{PP}, \mathrm{e}}$ increased from $2{ }^{\circ} \mathrm{C}$ to $21^{\circ} \mathrm{C}$.

Kaşka et al. [4] conducted a study on the energy and exergy analysis of the Organic Rankine-Brayton combined cycle. They found that it is important to determine the optimum $\Delta \mathrm{T}_{\mathrm{PP}, \mathrm{e}}$ temperature in heat exchangers where heat source and work fluid heat transfer occurs in ORC design. They stated that while the heat transfer to the evaporator increases linearly with the increase of the $\Delta \mathrm{T}_{\mathrm{PP}, \mathrm{e}}$ value, the thermal efficiency of the ORC decreases, but depending on the $\Delta \mathrm{T}_{\mathrm{PP}, \mathrm{e}}$ value, the net power produced by the ORC is the optimum point.

Sun et al. [5] examined the effect of $\Delta \mathrm{T}_{\mathrm{PP}, \mathrm{e}}$ on thermodynamic performance within the scope of geothermal ORC applications. They stated that $\Delta \mathrm{T}_{\mathrm{PP}, \mathrm{e}}$ is an important parameter for thermodynamic and economic performance. They have determined that low $\Delta \mathrm{T}_{\mathrm{PP}, \mathrm{e}}$ will provide more turbine net power but have a negative effect on the economy as it will increase the heat transfer area. For heat source applications higher than $130{ }^{\circ} \mathrm{C}$, it has been determined that ORC produces $1.7-2.6 \%$ more power with every $1{ }^{\circ} \mathrm{C}$ decrease in $\Delta \mathrm{T}_{\mathrm{PP}, \mathrm{e}}$.

Bademlioğlu et al. [6] studied the effect of $\Delta \mathrm{T}_{\mathrm{PP}, \mathrm{e}}$ on exergy performance in ORC. The effect of changing $\Delta \mathrm{T}_{\mathrm{PP}, \mathrm{e}}$ between $5-20{ }^{\circ} \mathrm{C}$ on systems prepared using different organic fluids has been determined. They stated that depending on the $\Delta \mathrm{T}_{\mathrm{PP}, \mathrm{e}}$ and the organic fluid, the irreversibility in the evaporator can be reduced by $62.32 \%$.

Wang et al. [7] have worked on $\Delta \mathrm{T}_{\mathrm{PP}, \mathrm{e}}$ optimization using the Analytical Hierarchy Process (AHP) - Entropy method in ORC systems. As a result of the study, they stated that they reached the maximum power output with $\mathrm{R} 141 \mathrm{~b}$ and the maximum thermal efficiency and exergy efficiency values with R11.

Sarkar [8] worked on $\Delta \mathrm{T}_{\mathrm{PP}, \mathrm{e}}$ design and optimization for maximum heat recovery in ORC. He developed a method that can determine $\Delta \mathrm{T}_{\mathrm{PP}, \mathrm{e}}$ and $\Delta \mathrm{T}_{\mathrm{PP}, \mathrm{c}}$ instantaneously. Best results have been achieved in ammonia fluid in terms of low mass flow requirement, high exergy efficiency and low turbine size at optimum points. In terms of high-power output and heat recovery efficiency, it performed better in isopentane fluid.

Jankowski et al. [9] determined the optimum $\Delta \mathrm{T}_{\mathrm{PP}, \mathrm{e}}$ value in ORC systems using the multi-objective approach technique. They worked on two objective functions: economy and environment. At the end of their studies, they reached the optimum $\Delta \mathrm{T}_{\mathrm{PP}, \mathrm{e}}$ between $7-10^{\circ} \mathrm{C}$ by using $\mathrm{R} 245 \mathrm{fa}$ fluid.
Imran et al. [10] conducted an optimization study by aiming thermal efficiency maximization and unit investment cost minimization with NSGA-II method. Evaporation pressure, superheating temperature and $\Delta \mathrm{T}_{\mathrm{PP}, \mathrm{e}}-\Delta \mathrm{T}_{\mathrm{PP}, \mathrm{c}}$ values were chosen as design parameters.

In the section below, the differences of the number of objective functions in optimization with GA are examined. In some studies, the objective function was determined through a single parameter in GA optimization. The objective functions; Bian et al. [11] determined the heat transfer area as the ratio of the total net power output, and Long et al. [12] decided the total exergy efficiency. Gutierrez et al. [13] accepted gross annual profit as an objective function, Han et al. [14] as a total irreversibility loss, Pierobon et al. [15] as a thermal efficiency, Agromayor et al. [16] as a second law efficiency. Finally, Andreasen et al. [17], Fiaschi et al. [18] and Kai et al. [19] used the net power as the objective function and studied both the optimum fluid selection and the thermodynamic optimization of the system with GA.

In this study, thermodynamic optimization has been made in order to find the optimum $\Delta \mathrm{T}_{\mathrm{PP}, \mathrm{e}}$ point for ORC designed using different fluids. As can be seen from the literature studies, it is stated that the maximum turbine power is not obtained due to the absorption of heat in the evaporator at the point where the thermal efficiency reaches its maximum. It has been determined that while the thermal efficiency decreases with the increase of $\Delta \mathrm{T}_{\mathrm{PP}, \mathrm{e}}$ value, the turbine power is not in the same trend. It was observed that the turbine power of the system started to decrease after a certain $\Delta T_{P P, e}$ value. With the change of $\Delta \mathrm{T}_{\mathrm{PP}, \mathrm{e}}$, the heat input required to be provided to the system increased, however, the mass flow rate of the organic fluid increased. But at the same time, with the change of $\Delta \mathrm{T}_{\mathrm{PP}, \mathrm{e}}$, the evaporation pressure decreased and the enthalpy difference in the turbine decreased. It has been determined that the turbine power of the system starts to decrease at the point where the decrease in the enthalpy difference is more than the increase in ORC mass flow rate.

Therefore, it was observed that the optimum $\Delta \mathrm{T}_{\mathrm{PP}, \mathrm{e}}$ point depends on the organic fluid and the heat source temperature. In the studies, it was determined that taking a constant $\Delta \mathrm{T}_{\mathrm{PP}, \mathrm{e}}$ value caused a certain amount of error in the analysis results. In this study, the optimum $\Delta \mathrm{T}_{\mathrm{PP}, \mathrm{e}}$ point of organic fluids in different categories at different heat source temperatures under various ORC applications was determined. These applications; geothermal, low temperature solar, waste heat and biomass-high temperature solar. Organic fluids have been selected for low temperature ORC from dry, isentropic, wet and new-generation organic fluids. In high temperature ORC, fluids have been chosen from among alkanes, aromatic hydrocarbons and siloxanes.

For low temperature ORC;

- Geothermal Energy Applications $\left(\mathrm{T}_{\mathrm{h}, \mathrm{i}}=90,100\right.$, $110^{\circ} \mathrm{C}$ )

- Low Temperature Solar Energy Applications $\left(\mathrm{T}_{\mathrm{h}, \mathrm{i}}=\right.$ $120,130^{\circ} \mathrm{C}$ )

For high temperature ORC;

- Waste Heat Applications $\left(\mathrm{T}_{\mathrm{h}, \mathrm{i}}=250,260,270{ }^{\circ} \mathrm{C}\right)$ 
- Biomass and High Temperature Solar Energy Applications $\left(\mathrm{T}_{\mathrm{h}, \mathrm{i}}=280,290^{\circ} \mathrm{C}\right)$

Li [20], in his review study, examined the organic fluid performance under different application areas (geothermal, low temperature solar, waste heat and biomass-high temperature solar) of ORC according to the heat source temperatures.

By using the temperature values determined for these applications, the effect of optimum pinch point temperature on turbine power maximization on different fluids has been determined.

In previous studies, it was observed that the $\Delta \mathrm{T}_{\mathrm{PP}, \mathrm{e}}$ value was taken as constant. However, the optimum $\Delta \mathrm{T}_{\mathrm{PP}, \mathrm{e}}$ value changes depending on the heat source temperature and the organic fluid. Based on these two factors, it is aimed to make an optimization study by determining the turbine power maximization purpose under the optimum $\Delta \mathrm{T}_{\mathrm{PP}, \mathrm{e}}$. By determining the optimum $\Delta \mathrm{T}_{\mathrm{PP}, \mathrm{e}}$ points for different applications of ORC, it is aimed to reach higher system performances in thermodynamic analysis, modeling and optimization studies conducted by the researchers.

\section{MATERIALS AND METHODS}

\subsection{Thermodynamic Analysis}

Engineering Equation Solver (EES) was used for thermodynamic analysis and optimization of ORC. Energy and mass equations for $\Delta \mathrm{T}_{\mathrm{PP}, \mathrm{e}}$ is introduced to EES, boundary conditions are entered for optimization using EES and genetic algorithm interface.

Table 1 and Table 2 summarizes the thermophysical and safety-environmental properties of fluids for low and high temperature ORC fluids respectively. The thermophysical properties of the fluid are taken from the "ASHRAE Standard 34" table. [21].

General definitions and equations (1-4) for the system are given below.

Mass balance $($ Total Mass Input $=$ Total Mass Output $)$;

$\sum \dot{m}_{\text {input }}=\sum \dot{m}_{\text {out }}$

Energy balance (Total Energy Input = Total Energy Output);

$\sum E_{\text {input }}=\sum E_{\text {out }}$

$\dot{Q}-\dot{W}=\dot{m} *\left(h_{\text {in }}-h_{\text {out }}\right)$

Exergy balance $($ Total Exergy input $=$ Final Exergy + Exergy Consumption + Exergy Destruction);

$\dot{E} x_{i n}=\dot{E} x_{f}+\dot{E} x_{c}+\dot{E} x_{d}$

Table 1. Thermophysical and safety-environmental properties of fluids for low-temperature ORC.

\begin{tabular}{lccccccccc}
\hline Fluids & R601 & R601a & R141b & R123 & R152a & R134a & R1234yf & R1234ze \\
\hline Type & \multicolumn{2}{c}{ Dry } & \multicolumn{2}{c}{ Isentropic } & & Wet & & New-Generations \\
\hline Molecular mass $(\mathrm{g} / \mathrm{mol})$ & 72.15 & 72.15 & 116.95 & 152.93 & 66.05 & 102 & 114.04 & 114.04 \\
\hline Normal Boiling Points $\left({ }^{\circ} \mathrm{C}\right)$ & 36.1 & 27,8 & 32 & 27,8 & -24 & -26.1 & -29.3 & -18.8 \\
\hline Critical Temperature $\left({ }^{\circ} \mathrm{C}\right)$ & 196.6 & 187.2 & 204.4 & 183.7 & 113.3 & 101.1 & 94.85 & 109.52 \\
\hline Critical Pressure $(\mathrm{MPa})$ & 3.37 & 3.38 & 4.21 & 3.66 & 4.52 & 4.06 & 3.38 & 3.63 \\
\hline ASHRAE 34 safety group & A3 & A3 & n.a & B1 & A2 & A1 & ${ }^{*}$ A2L & $*$ A2L \\
\hline ODP & 0 & 0 & 0.12 & 0 & 0 & 0 & 0 & 0 \\
\hline GWP & 20 & 20 & 725 & 77 & 124 & 1430 & 4 & 6 \\
\hline
\end{tabular}

Table 2. Thermophysical and safety-environmental properties of fluids for high-temperature ORC.

\begin{tabular}{|c|c|c|c|c|c|c|}
\hline Fluids & n-octane & cyclohexane & benzene & toluene & $\mathrm{MM}$ & D4 \\
\hline Type & \multicolumn{2}{|c|}{ Alkanes } & \multicolumn{2}{|c|}{ Aromatic Hydrocarbons } & \multicolumn{2}{|c|}{ Siloxanes } \\
\hline Molecular mass (g/mol) & 114.23 & 84.161 & 78.108 & 92.138 & 162.4 & 296.6 \\
\hline Normal Boiling Points $\left({ }^{\circ} \mathrm{C}\right)$ & 125 & 80 & 80 & 110 & 100.4 & 175 \\
\hline Critical Temperature $\left({ }^{\circ} \mathrm{C}\right)$ & 296 & 280 & 289 & 319 & 245 & 312 \\
\hline Critical Pressure (MPa) & 2.49 & 4.075 & 4.89 & 4.12 & 1.91 & 1.33 \\
\hline ASHRAE 34 safety group & n.a & A3 & B2 & A3 & n.a & n.a \\
\hline ODP & n.a & 0 & 0 & 0 & n.a & n.a \\
\hline GWP & n.a & low & low & 2.7 & n.a & n.a \\
\hline
\end{tabular}

*A2L; low toxicity and mildly flammable 
In the energy analysis of the components in the system, the equations used for pump work (5), evaporator heat input (6), turbine work (7), the amount of heat discharged from the condenser (8) are given below (Isentropic efficiencies of turbine and pump, $\eta_{\mathrm{t}}$ and $\eta_{\mathrm{p}}$, respectively).

$W_{p}=\left(h_{2}-h_{1}\right)=\left(h_{2 s}-h_{1}\right) / \eta_{p}$

$Q_{e}=\left(h_{3}-h_{2}\right)$

$W_{t}=\left(h_{3}-h_{4}\right)=\left(h_{3}-h_{4 s}\right) \eta_{t}$

$Q_{c}=\left(h_{4}-h_{1}\right)$

The equations used for net work (9) and thermal efficiency (10) in the system are given below.

$W_{n e t}=W_{t}-W_{p}$

$\eta_{t h}=W_{\text {net }} / Q_{e}$

The irreversibility equations used for the pump (11), evaporator (12), turbine (13) and condenser (14) in the exergy analysis of the components in the system are given below. The average temperatures of the heat source and cooling water are given in Equation 15-16.

$i_{p}=T_{0}\left(s_{2}-s_{1}\right)$

$i_{e}=T_{0}\left[\left(s_{3}-s_{2}\right)-\left(h_{3}-h_{2}\right) / T_{h}\right]$

$i_{t}=T_{0}\left(s_{4}-s_{3}\right)$

$$
\begin{aligned}
& i_{c}=T_{0}\left[\left(s_{1}-s_{4}\right)+\left(h_{4}-h_{1}\right) / T_{c}\right] \\
& T_{h}=\left(T_{h, i}-T_{h, o}\right) / \operatorname{Ln}\left(T_{h, i}-T_{h, o}\right) \\
& T_{c}=\left(T_{c, i}-T_{c, o}\right) / \operatorname{Ln}\left(T_{c, i}-T_{c, o}\right)
\end{aligned}
$$

The equations used for total irreversibility (17), consumed exergy (18) and exergy efficiency (19) in the system are given below.

$$
\begin{aligned}
& i_{\text {Total }}=i_{p}+i_{e}+i_{t}+i_{c} \\
& e_{\text {consumed }}=\left[1-T_{0} / T_{h}\right] Q_{e}+W_{p} \\
& \eta_{I I}=1-i_{\text {Total }} / e_{\text {consumed }}
\end{aligned}
$$

The working principle of ORC and the demonstration of $\Delta \mathrm{T}_{\mathrm{PP}, \mathrm{e}}$ is given in Figure 1. The evaporator and condenser energy balance relations (Eq.20-26) are given below. The explanations of the symbols in these equations are given below.

- $\mathrm{T}_{\mathrm{p}, \mathrm{e}}:$ Evaporator pinch point temperature

- $\mathrm{T}_{3, \mathrm{f}}$ : Evaporation temperature

- $\Delta \mathrm{T}_{\mathrm{PP}, \mathrm{e}}:$ Evaporator pinch point temperature difference

- $\mathrm{T}_{\mathrm{p}, \mathrm{c}}$ : Condenser pinch point temperature;

- $\mathrm{T}_{1, \mathrm{~g}}$ : Condensation temperature

- $\Delta \mathrm{T}_{\mathrm{PP}, \mathrm{c}}$ : Condenser pinch point temperature difference

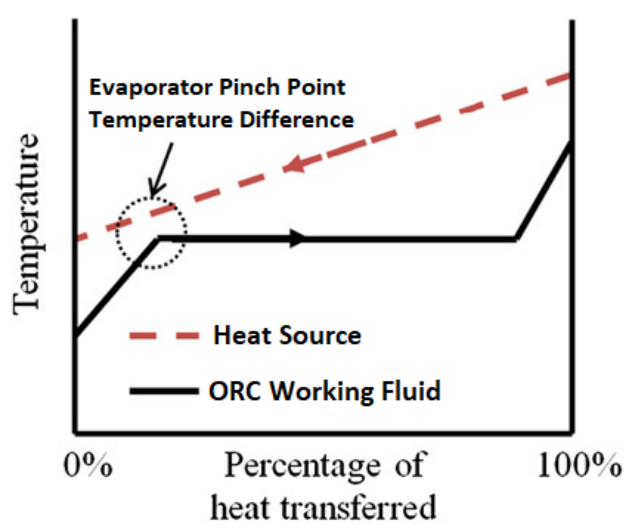

Figure 1. ORC Working Principle and Demonstration of evaporator pinch point temperature difference $\left(\Delta \mathrm{T}_{\mathrm{PP}, \mathrm{e}}\right)[22]$

Evaporator energy balance

$\dot{\mathrm{m}}_{O R C} *\left(h_{3}-h_{2}\right)=\dot{\mathrm{m}}_{h} * C p *\left(T_{h, i}-T_{h, o}\right)$

$\dot{\mathrm{m}}_{O R C} *\left(h_{3}-h_{3, f}\right)=\dot{\mathrm{m}}_{h} * C p *\left(T_{h, i}-T_{p, e}\right)$

$\Delta T p p_{, e}=\left(T_{p, e}-T_{3, f}\right)$

Evaporator effectiveness $(\varepsilon)$

$$
\varepsilon=\frac{Q}{Q_{\max }}=\frac{\dot{\mathrm{m}}_{h} * \mathrm{Cp} *\left(T_{h, i}-T_{h, o}\right)}{\dot{\mathrm{m}}_{h} * \mathrm{Cp} *\left(T_{h, i}-T_{2}\right)}=\frac{\left(T_{h, i}-T_{h, o}\right)}{\left(T_{h, i}-T_{2}\right)}
$$

Condenser energy balance

$$
\begin{aligned}
& \dot{\mathrm{m}}_{O R C} *\left(h_{4 a}-h_{1}\right)=\dot{\mathrm{m}}_{c} * C p *\left(T_{c, o}-T_{c, i}\right) \\
& \dot{\mathrm{m}}_{O R C} *\left(h_{1, g}-h_{1}\right)=\dot{\mathrm{m}}_{c} * C p *\left(T_{p, c}-T_{c, i}\right)
\end{aligned}
$$


$\Delta T p p,_{c}=\left(T_{1, g}-T_{p, c}\right)$

For the thermodynamic analysis of ORC, the following assumptions are employed.

- All processes are under steady state.

- Pressure losses in the evaporator and condenser are neglected. Losses in pipelines are neglected.

- In the analysis, all equipment is considered adiabatic and it is assumed that there is no heat transfer between its surfaces and the environment.

- Potential and kinetic energy changes have been neglected.

- Low-temperature ORC heat source temperatures: $90,100,110,120$ and $130{ }^{\circ} \mathrm{C}$

- High-temperature ORC heat source temperatures: $250,260,270,280$ and $290{ }^{\circ} \mathrm{C}$

- Heat source mass flow rate is $0.27 \mathrm{~kg} / \mathrm{s}$.

- Isentropic efficiency of the turbine and the pump are $75 \%$.

- $\quad$ Evaporator effectiveness is $75 \%$

- Cooling water inlet temperature $\left(\mathrm{T}_{\mathrm{c}, \mathrm{i}}\right) 27^{\circ} \mathrm{C}$.

- Dead point pressure and temperature, respectively, P0: $100 \mathrm{kPa}$ and $\mathrm{T} 0: 25^{\circ} \mathrm{C}$

\subsection{Thermodynamic Optimization with GA}

In this study, the effect of $\Delta \mathrm{T}_{\mathrm{PP}, \mathrm{e}}$ on ORC was determined by Genetic Algorithm (GA). Tournament selection method was used for the optimization of the simple ORC with the genetic algorithm. Control parameters for optimization are shown in below. Flow diagram of GA's working principle is shown in Figure 2.

Control parameters of GA for the optimization:

- Population size is 65 .

- Maximum generations are 256.

- Crossover probability is 0.7 .

- Mutation probability is 0.175 .

- Selection process is "Tournament".

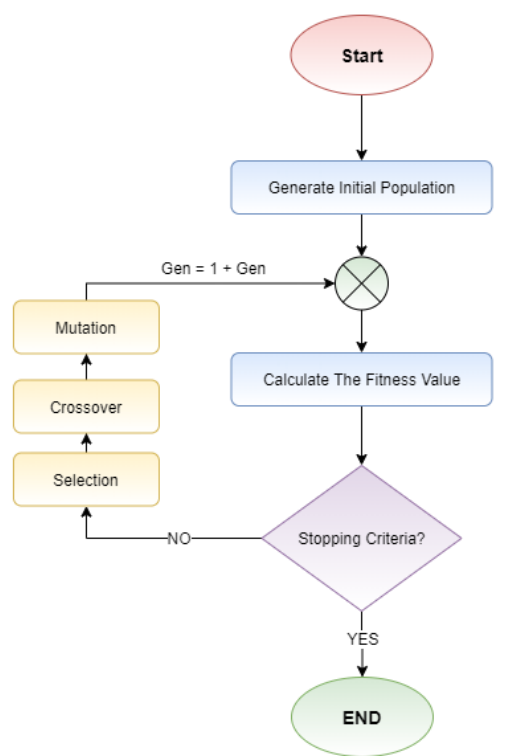

Figure 2. Flow chart of the genetic algorithms.
Thermodynamic optimization is performed using genetic algorithm. The lowest turbine power in the system is $1 \mathrm{~kW}$; the highest turbine power has been set as $10 \mathrm{~kW}$ and $50 \mathrm{~kW}$ for low and high temperature ORC respectively. The primary working conditions are selected as decision variables which include evaporating pressure $\left(\mathrm{P}_{\mathrm{eva}}\right), \Delta \mathrm{T}_{\mathrm{PP}, \mathrm{e}}, \Delta \mathrm{T}_{\mathrm{PP}, \mathrm{c}}$ and superheating temperature $\left(\mathrm{T}_{\text {sup }}\right)$. Since organic fluids in different fluid categories are used in the design, the limit values for evaporation pressure have been determined at different ranges. In this way, better results were obtained in optimization. Table 3 summarizes the logical bounds for four decision variables for low-high temperature ORC respectively.

Based on the energy balance and the definition of evaporator and condenser pinch point temperature difference, other following constraints are considered in the optimization. Thermodynamic optimization was applied separately for 3 different heat source temperatures. Therefore, the limitations that should be related to the heat source temperature are also specified.

- $1 \mathrm{~kW}<\mathrm{W}_{\mathrm{T}}<10 \mathrm{~kW}$ (for low-temperature ORC)

- $1 \mathrm{~kW}<\mathrm{W}_{\mathrm{T}}<50 \mathrm{~kW}$ (for high-temperature ORC)

- $\mathrm{T}_{\mathrm{eva}}+\Delta \mathrm{T}_{\mathrm{PP}, \mathrm{e}}<\mathrm{T}_{\mathrm{h}, \mathrm{i}}$

- $\mathrm{T}_{\mathrm{eva}}+\Delta \mathrm{T}_{\mathrm{PP}, \mathrm{e}}<\mathrm{T}_{\text {critical }}$

- $\mathrm{T}_{\mathrm{eva}}+\mathrm{T}_{\text {sup }}<\mathrm{T}_{\mathrm{h}, \mathrm{i}}$

- $\mathrm{T}_{\mathrm{c}, \mathrm{i}}+\Delta \mathrm{T}_{\mathrm{PP}, \mathrm{c}}<\mathrm{T}_{\text {con }}$

- $\mathrm{T}_{\text {eva,min }}: 70^{\circ} \mathrm{C}$

By changing the $\Delta \mathrm{T}_{\mathrm{PP}, \mathrm{e}}$ value, the heat input provided to the system, the mass flow of organic fluid, the evaporation pressure and the enthalpy drop in the turbine are affected.

Four important parameters are affected by the change of $\Delta \mathrm{T}_{\mathrm{PP}, \mathrm{e}}$ value in ORC system. These are; the heat input provided to the system, the mass flow of organic fluid, the evaporation pressure and the enthalpy drop in the turbine. It has been determined that the turbine power of the system starts to decrease at the point where the decrease in the enthalpy difference is more than the increase in ORC mass flow rate. Therefore, the objective function in this study was determined as turbine power maximization.

Objective Function;

- $\quad \mathrm{f}(\mathrm{x})$ : $\max (\mathrm{WT})$; Turbine power maximization

where $\mathrm{x}=\left\{\mathrm{P}_{\mathrm{eva}}, \Delta \mathrm{T}_{\mathrm{PP}, \mathrm{e}}, \Delta \mathrm{T}_{\mathrm{PP}, \mathrm{c}}, \mathrm{T}_{\text {sup }}\right\}$ subjected to lower bound $<\mathrm{x}<$ upper bound.

\section{MODEL VALIDATION}

In order to determine the accuracy of the data obtained using GA, two studies investigated within the scope of literature research were used. The net power values determined by using three different organic fluids under the same design parameters were compared for two different studies in Table 4. When Table 4 is examined, it is seen that the thermodynamic model prepared can be used successfully 
Table 3. Logical bounds for four decision variables for low and high temperature ORC.

\begin{tabular}{|c|c|c|c|c|}
\hline \multicolumn{5}{|c|}{ Low-temperature ORC } \\
\hline Organic Fluids & Evaporating Pressure $\left(\mathrm{P}_{\text {eva }}\right)(\mathrm{kPa})$ & $\Delta \mathbf{T}_{\mathrm{PP}, \mathrm{e}}\left({ }^{\circ} \mathbf{C}\right)$ & $\Delta \mathbf{T}_{\mathbf{P P}, \mathrm{c}}\left({ }^{\circ} \mathbf{C}\right)$ & Tsup $\left({ }^{\circ} \mathrm{C}\right)$ \\
\hline $\mathbf{R 6 0 1}$ & $260<\mathrm{P}_{\mathrm{eva}}<410$ & \multirow{8}{*}{$1<\Delta \mathrm{T}_{\mathrm{PP}, \mathrm{e}}<15$} & \multirow{8}{*}{$1<\Delta \mathrm{T}_{\mathrm{PP}, \mathrm{c}}<10$} & \multirow{8}{*}{$0<$ Tsup $<20$} \\
\hline R601a & $330<\mathrm{P}_{\mathrm{eva}}<510$ & & & \\
\hline R141b & $300<\mathrm{P}_{\mathrm{eva}}<470$ & & & \\
\hline $\mathbf{R 1 2 3}$ & $350<\mathrm{P}_{\mathrm{eva}}<550$ & & & \\
\hline R152a & $1840<\mathrm{P}_{\text {eva }}<4250$ & & & \\
\hline R134a & $2100<\mathrm{P}_{\mathrm{eva}}<3900$ & & & \\
\hline R1234yf & $2000<\mathrm{P}_{\mathrm{eva}}<3300$ & & & \\
\hline R1234ze & $1600<\mathrm{P}_{\mathrm{eva}}<3410$ & & & \\
\hline \multicolumn{5}{|c|}{ High-temperature ORC } \\
\hline Organic Fluids & Evaporating Pressure $\left(\mathrm{P}_{\text {eva }}\right)(\mathbf{k P a})$ & $\Delta \mathbf{T P P}_{\mathrm{e}}\left({ }^{\circ} \mathbf{C}\right)$ & $\left.\Delta \mathbf{T P P}_{\mathbf{P}, \mathrm{c}}{ }^{\circ} \mathrm{C}\right)$ & Tsup $\left({ }^{\circ} \mathbf{C}\right)$ \\
\hline n-octane & $200<\mathrm{P}_{\mathrm{eva}}<400$ & \multirow{6}{*}{$1<\Delta T_{P P, e}<40$} & \multirow{6}{*}{$1<\Delta \mathrm{T}_{\mathrm{PP}, \mathrm{c}}<10$} & \multirow{6}{*}{$0<$ Tsup $<20$} \\
\hline cyclohexane & $590<\mathrm{P}_{\mathrm{eva}}<1150$ & & & \\
\hline benzene & $550<\mathrm{P}_{\mathrm{eva}}<1100$ & & & \\
\hline toluene & $270<\mathrm{P}_{\mathrm{eva}}<480$ & & & \\
\hline D4 & $50<\mathrm{P}_{\mathrm{eva}}<130$ & & & \\
\hline MM & $460<\mathrm{P}_{\mathrm{eva}}<1270$ & & & \\
\hline
\end{tabular}

Table 4. Comparison of important optimization results with literature under same design parameters (GA).

\begin{tabular}{|c|c|c|c|c|c|c|}
\hline $\begin{array}{c}\text { Design } \\
\text { Parameters }\end{array}$ & \multicolumn{4}{|c|}{$\begin{array}{l}\text { Heat Source Temperature: } 150^{\circ} \mathrm{C} \text {; } \\
\text { Heat Sink Temperature: } 20^{\circ} \mathrm{C} ; \\
\quad \Delta \mathrm{T}_{\mathrm{PP}, \mathrm{e}}+\Delta \mathrm{T}_{\mathrm{PP}, \mathrm{c}}=20^{\circ} \mathrm{C} \\
\text { and pump isentropic efficiency: } 85 \% \text { and } 80 \%\end{array}$} & \multirow{2}{*}{\multicolumn{2}{|c|}{$\begin{array}{c}\text { Evaporation Temperature: } 80^{\circ} \mathrm{C} \\
\Delta \mathrm{T}_{\mathrm{PP}, \mathrm{e}}=8{ }^{\circ} \mathrm{C} \\
\text { Turbine and pump isentropic } \\
\text { efficiency: } 80 \% \text { and } 70 \% \\
\mathrm{R} 245 \mathrm{fa}\end{array}$}} \\
\hline Organic Fluids & \multicolumn{2}{|c|}{ R113 } & \multicolumn{2}{|c|}{$\mathrm{R} 11$} & & \\
\hline $\begin{array}{l}\text { Performance } \\
\text { Parameters }\end{array}$ & Present Study & Literature [9] & Present Study & Literature [9] & Present Study & Literature [11] \\
\hline Net Power $(\mathrm{kW})$ & 73.12 & 73.91 & 70.24 & 70.93 & 50.2 & 51.0 \\
\hline
\end{tabular}

\section{RESULT AND DISCUSSION}

Figures 3 and 4 show the effect of $\Delta \mathrm{T}_{\mathrm{PP}, \mathrm{e}}$ change on turbine power in geothermal and low temperature solar energy applications of ORC, respectively. When GA optimization results are evaluated for low-temperature ORC;

- It has been determined that the turbine power decreases at the point where the enthalpy difference decrease is more than the mass flow increase at the other heat source temperatures except $90{ }^{\circ} \mathrm{C}$. Net power increased as $\Delta \mathrm{T}_{\mathrm{PP}, \mathrm{e}}$ increased, since mass flow rate increase was greater than enthalpy difference decreases at $90^{\circ} \mathrm{C}$.

- It was observed that the allowable $\Delta \mathrm{T}_{\mathrm{PP}, \mathrm{e}}$ value according to the minimum evaporator temperature under $90{ }^{\circ} \mathrm{C}$ heat source temperature is $5{ }^{\circ} \mathrm{C}$ maximum.

- In low-temperature applications of ORC, the highest turbine power has been reached in the system with R1234yf. Also, ORC systems with $\mathrm{R} 1234$ ze at $90{ }^{\circ} \mathrm{C}$ and R134a at 100 and $110{ }^{\circ} \mathrm{C}$ performed better.
- While $\Delta \mathrm{T}_{\mathrm{PP}, \mathrm{e}}$ 's effect on turbine power tends to be similar in dry and isentropic fluids, it is very different in wet and new-generation fluids.

- It is seen that the turbine power starts to decrease after a certain $\Delta \mathrm{T}_{\mathrm{PP}, \mathrm{e}}$ value at all heat source temperatures except $90{ }^{\circ} \mathrm{C}$ heat source temperature.

- Especially in low temperature solar energy applications, for wet fluid and new-generation organic fluids, the effect of $\Delta \mathrm{T}_{\mathrm{PP}, \mathrm{e}}$ on turbine power is different than other fluids.

- In dry and isentropic fluids, low turbine power was obtained at low $\Delta \mathrm{T}_{\mathrm{PP}, \mathrm{e}}$ values. As $\Delta \mathrm{T}_{\mathrm{PP}, \mathrm{e}}$ increased, the turbine power value increased and decreased after a certain value due to the ORC mass flow rate and enthalpy drop in turbine.

- However, in wet fluid and new-generation organic fluids, a high turbine power value was achieved at the minimum $\Delta \mathrm{T}_{\mathrm{PP}, \mathrm{e}}$ value allowed by the optimization limit values and it was observed that the turbine power remained at the same rate or started to decrease directly as $\Delta \mathrm{T}_{\mathrm{PP}, \mathrm{e}}$ increased.

- Due to the low critical temperature of wet and newgeneration fluids, the minimum $\Delta \mathrm{T}_{\mathrm{PP}, \mathrm{e}}$ point increased as the heat source temperature increased. 


\section{GEOTHERMAL APPLICATIONS}
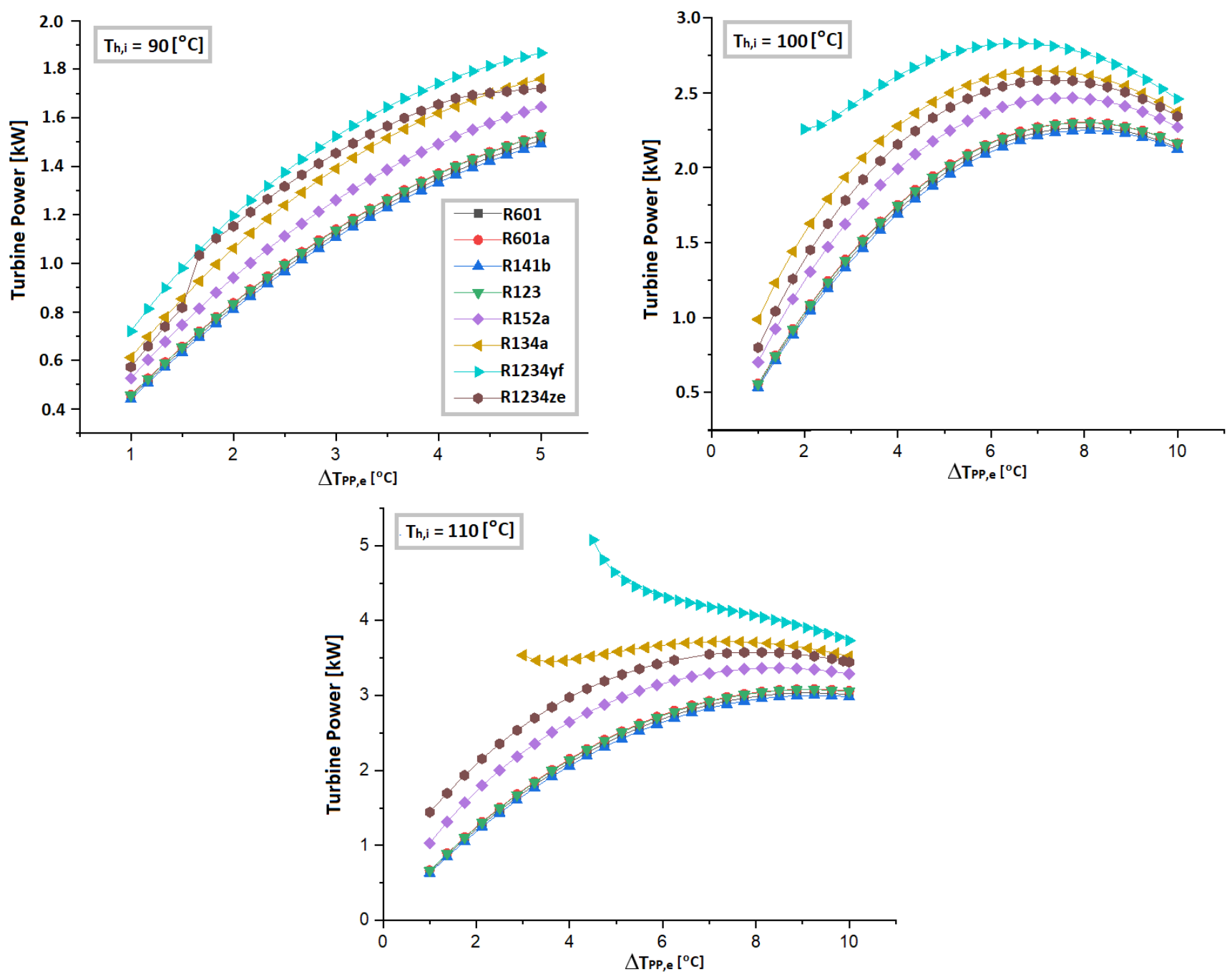

Figure 3. Effect of $\Delta \mathrm{T}_{\mathrm{PP}, \mathrm{e}}$ change on turbine power for 90,100 and $110^{\circ} \mathrm{C}$ heat source temperatures in ORC's geothermal applications.
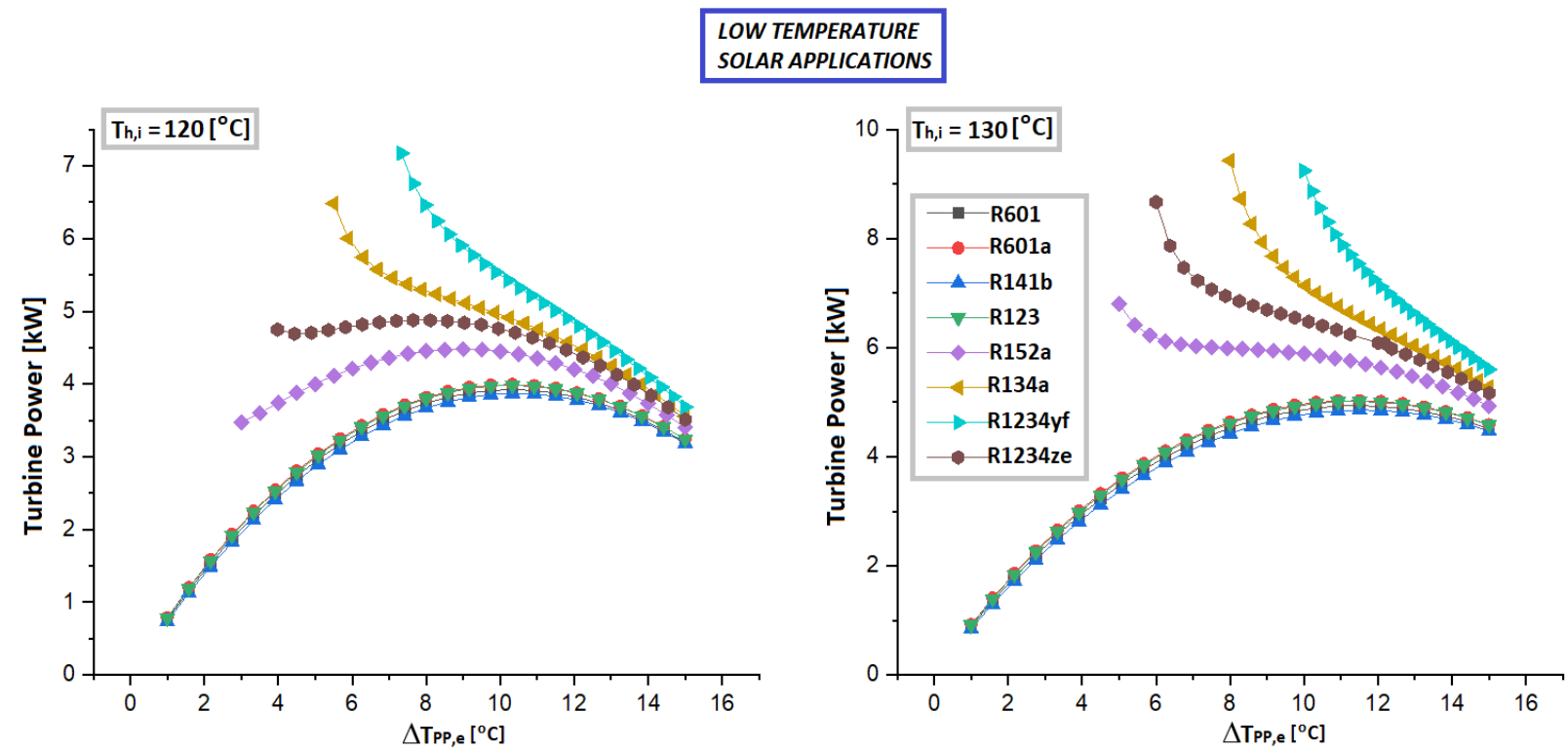

Figure 4. Effect of $\Delta \mathrm{T}_{\mathrm{PP}, \mathrm{e}}$ change on turbine power for 120 and $130{ }^{\circ} \mathrm{C}$ heat source temperatures in ORC's low temperature solar applications. 
The optimum $\Delta \mathrm{T}_{\mathrm{PP}, \mathrm{e}}$ points where the maximum turbine power is obtained under 5 different heat source temperatures of 8 different fluids are summarized in Table 5. It is noteworthy that the $\Delta T_{\mathrm{PP}, \mathrm{e}}$ value is the same in all fluids at
$90{ }^{\circ} \mathrm{C}$ heat source temperature. In addition, it has been determined that dry and isentropic fluids have the same $\Delta \mathrm{T}_{\mathrm{PP}, \mathrm{e}}$ value at other temperatures.

Table 5. Determination of optimum $\triangle \mathrm{TPP}, \mathrm{e}$ value for different fluids under different heat source temperatures for low temperature ORC applications.

\begin{tabular}{|c|c|c|c|c|c|c|c|c|}
\hline \multirow[t]{2}{*}{$\mathrm{T}_{\mathrm{h}, \mathrm{i}}$} & \multicolumn{8}{|c|}{ Optimum $\Delta \mathrm{T}_{\mathrm{PP}, \mathrm{e}}\left({ }^{\circ} \mathrm{C}\right)$} \\
\hline & R601a & R601 & R141b & R123 & R152a & R134a & R1234yf & R1234ze \\
\hline $90{ }^{\circ} \mathrm{C}$ & \multicolumn{8}{|c|}{5} \\
\hline $100{ }^{\circ} \mathrm{C}$ & \multicolumn{4}{|c|}{8.125} & 7.75 & 7 & 6.67 & 7.38 \\
\hline $110^{\circ} \mathrm{C}$ & \multicolumn{4}{|c|}{9.25} & 8.5 & 7.375 & 4.5 & 8.125 \\
\hline $120^{\circ} \mathrm{C}$ & \multicolumn{4}{|c|}{10.33} & 9 & 5.5 & 7.33 & 3.98 \\
\hline $130^{\circ} \mathrm{C}$ & \multicolumn{4}{|c|}{11.5} & 5 & 8 & 10 & 6 \\
\hline
\end{tabular}

Figures 5 and 6 show the effect of $\Delta \mathrm{T}_{\mathrm{PP}, \mathrm{e}}$ change on turbine power in waste heat and biomass-high temperature solar energy applications of ORC, respectively. When GA optimization results are evaluated for high-temperature ORC;

- In high temperature applications of ORC, the highest turbine power was achieved in the siloxanes group.

- The highest turbine power has been reached in the system with MM. It has been observed that benzene and toluene, which are aromatic hydrocarbons, perform worse than other fluids.

- It is seen that the turbine power starts to decrease after a certain $\Delta \mathrm{T}_{\mathrm{PP}, \mathrm{e}}$ value at all heat source temperatures except MM fluid.

- Since MM has a lower critical temperature compared to other fluids, as the heat source temperature increased, the minimum $\Delta \mathrm{T}_{\mathrm{PP}, \mathrm{e}}$ point increased.

The optimum $\Delta \mathrm{T}_{\mathrm{PP}, \mathrm{e}}$ points where the maximum turbine power is obtained under 5 different heat source temperatures of 6 different fluids are summarized in Table 6 . It was stated that very close $\Delta \mathrm{T}_{\mathrm{PP}, \mathrm{e}}$ values were obtained in fluids in the same fluid group. It is seen that MM, which has a lower critical temperature compared to other fluids, has a lower optimum $\Delta \mathrm{T}_{\mathrm{PP}, \mathrm{e}}$ value from $280^{\circ} \mathrm{C}$.

In the last part of the study, the loss of performance due to constant $\Delta \mathrm{T}_{\mathrm{PP}, \mathrm{e}}$ values were investigated. It was seen from the literature research that the constant $\Delta \mathrm{T}_{\mathrm{PP}, \mathrm{e}}$ value in low and high temperature ORC's was taken as 5 and $20{ }^{\circ} \mathrm{C}$, respectively. In systems where the heat source temperature is higher than $90^{\circ} \mathrm{C}$, it is seen that taking $\Delta \mathrm{T}_{\mathrm{PP}, \mathrm{e}}$ as constant $5{ }^{\circ} \mathrm{C}$ causes performance loss. In low temperature ORC systems, it is seen that the performance loss increases as the heat source temperature increases. There was less performance change in high temperature ORC systems compared to low temperature systems. Performance comparison of all fluids used in thermodynamic design was made under constant and optimum $\Delta \mathrm{T}_{\mathrm{PP}, \mathrm{e}}$. On average, $38.7 \%$ and $5.9 \%$ higher turbine power was achieved for low and high temperature applications, respectively, in the optimum $\Delta \mathrm{T}_{\mathrm{PP}, \mathrm{e}}$ condition. An example of performance comparison from low and high temperature applications is given below.

- At $120^{\circ} \mathrm{C}$, the turbine power under constant $\Delta \mathrm{T}_{\mathrm{PP}, \mathrm{e}}$ $\left(5^{\circ} \mathrm{C}\right)$ in ORC system with $\mathrm{R} 141 \mathrm{~b}$ is $2.863 \mathrm{~kW}$, while it is $3.871 \mathrm{~kW}$ under optimum $\Delta \mathrm{T}_{\mathrm{PP}, \mathrm{e}}(10.33$ $\left.{ }^{\circ} \mathrm{C}\right)$. Under optimum $\Delta \mathrm{T}_{\mathrm{PP}, \mathrm{e}}, 35 \%$ performance increase was determined.

- At $270{ }^{\circ} \mathrm{C}$, the turbine power under constant $\Delta \mathrm{T}_{\mathrm{PP}, \mathrm{e}}$ $\left(20^{\circ} \mathrm{C}\right)$ in ORC system with benzene is $21.47 \mathrm{~kW}$, while it is $22.42 \mathrm{~kW}$ under optimum $\Delta \mathrm{T}_{\mathrm{PP}, \mathrm{e}}\left(27^{\circ} \mathrm{C}\right)$. Under optimum $\Delta \mathrm{T}_{\mathrm{PP}, \mathrm{e}}, \quad 4.42 \%$ performance increase was determined.

\section{CONCLUSIONS}

In this study, the effect of optimum $\Delta T_{P P, e}$ value on ORC performance was determined. Optimum $\Delta \mathrm{T}_{\mathrm{PP}, \mathrm{e}}$ values were determined under different applications by thermodynamic optimization with turbine power maximization.

In low temperature ORC applications,

- The performance of dry, isentropic, wet and newgeneration fluid groups was compared.

- The highest turbine power has been reached in the ORC system with R1234yf.

- While the effect of $\Delta \mathrm{T}_{\mathrm{PP}, \mathrm{e}}$ on turbine power has a similar tendency in dry and isentropic fluids, it has been different due to the low critical temperature of wet and new-generation fluids.

- It was stated that the optimum $\Delta \mathrm{T}_{\mathrm{PP}, \mathrm{e}}$ value for dry and isentropic fluids depends on the heat source temperature. In wet and new-generation fluids, it was determined that the optimum $\Delta \mathrm{T}_{\mathrm{PP}, \mathrm{e}}$ value depends on both the heat source temperature and the organic fluid. 
- For $90{ }^{\circ} \mathrm{C}$, it is seen that the optimum $\Delta \mathrm{T}_{\mathrm{PP}, \mathrm{e}}$ value is the same for all fluids. In ORC systems designed at heat source temperatures above $90{ }^{\circ} \mathrm{C}$, firstly, optimum $\Delta \mathrm{T}_{\mathrm{PP}, \mathrm{e}}$ values should be determined.

In high temperature ORC applications,

- The performance of alkanes, aromatic hydrocarbon and siloxane fluid groups were compared.

- The highest turbine power has been reached in the ORC system with MM.

- Since MM has a lower critical temperature than others, as the heat source temperature increased, the minimum $\Delta \mathrm{T}_{\mathrm{PP}, \mathrm{e}}$ value increased.

- Cyclohexane appears to be the fluid most affected by $\Delta \mathrm{T}_{\mathrm{PP}, \mathrm{e}}$ exchange. It is stated that it has higher turbine power than others at low $\Delta \mathrm{T}_{\mathrm{PP}, \mathrm{e}}$ values.
It has been determined that the effect of $\Delta \mathrm{T}_{\mathrm{PP}, \mathrm{e}}$ on turbine power is greater in low temperature ORC systems. Studies in which the $\Delta \mathrm{T}_{\mathrm{PP}, \mathrm{e}}$ value was taken as constant regardless of the heat source temperature and organic fluid were examined. It has been determined that $38.7 \%$ and $5.9 \%$ more turbine power will be achieved, respectively, for low and high temperature applications under optimum $\Delta \mathrm{T}_{\mathrm{PP}, \mathrm{e}}$.

Taking constant $\Delta \mathrm{T}_{\mathrm{PP}, \mathrm{e}}$, which has a very important place in ORC performance, causes seriously erroneous results in studies. Using optimum $\Delta \mathrm{T}_{\mathrm{PP}, \mathrm{e}}$ values determined depending on the heat source temperature and organic fluid will help achieve higher ORC performances. In thermodynamic analysis, modeling and simulation studies, it is recommended to determine the optimum $\Delta \mathrm{T}_{\mathrm{PP}, \mathrm{e}}$ value first.

WASTE HEAT APPLICATIONS
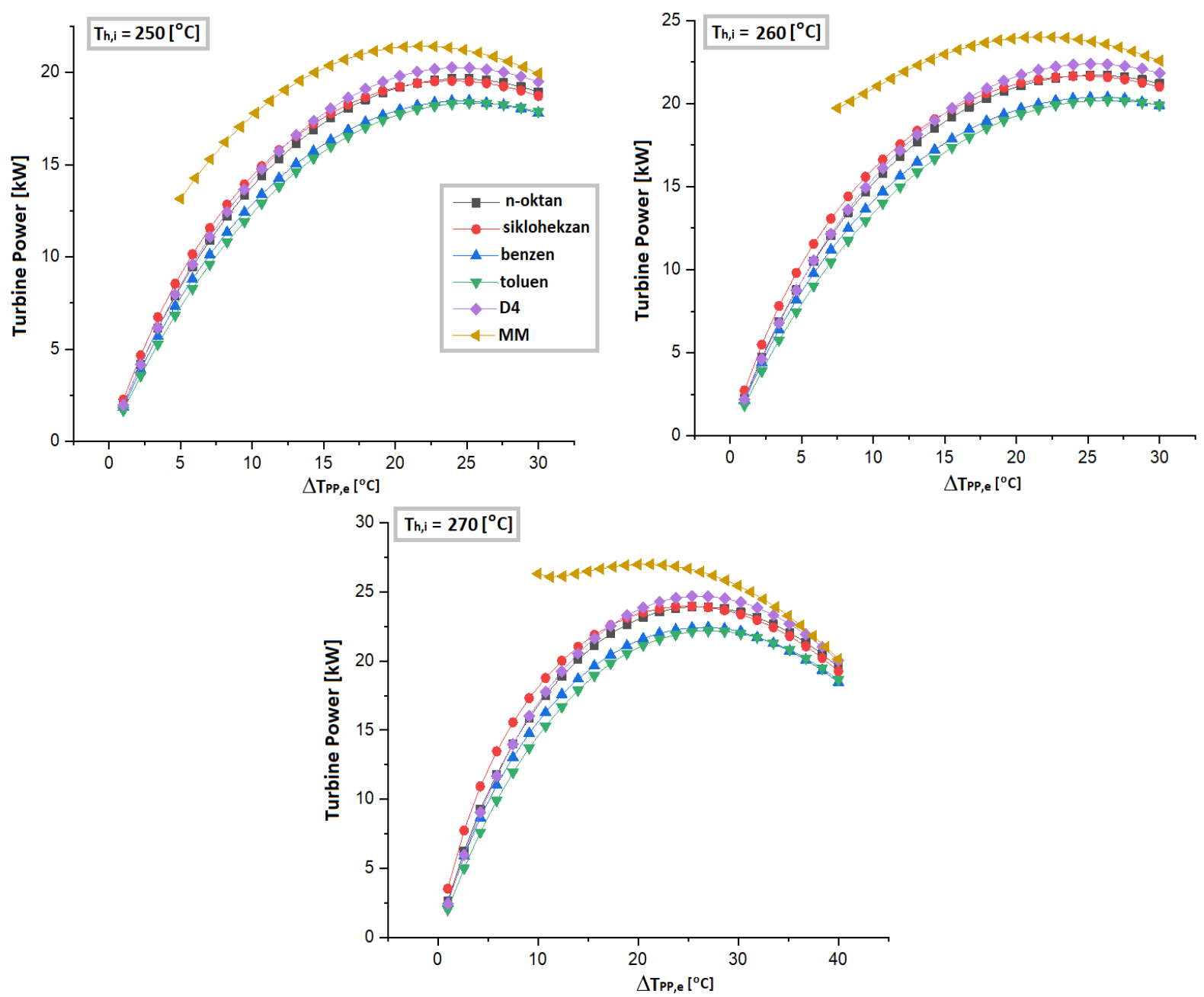

Figure 5. Effect of $\Delta \mathrm{T}_{\mathrm{PP}, \mathrm{e}}$ change on turbine power for 250,260 and $270{ }^{\circ} \mathrm{C}$ heat source temperatures in ORC's waste heat applications. 


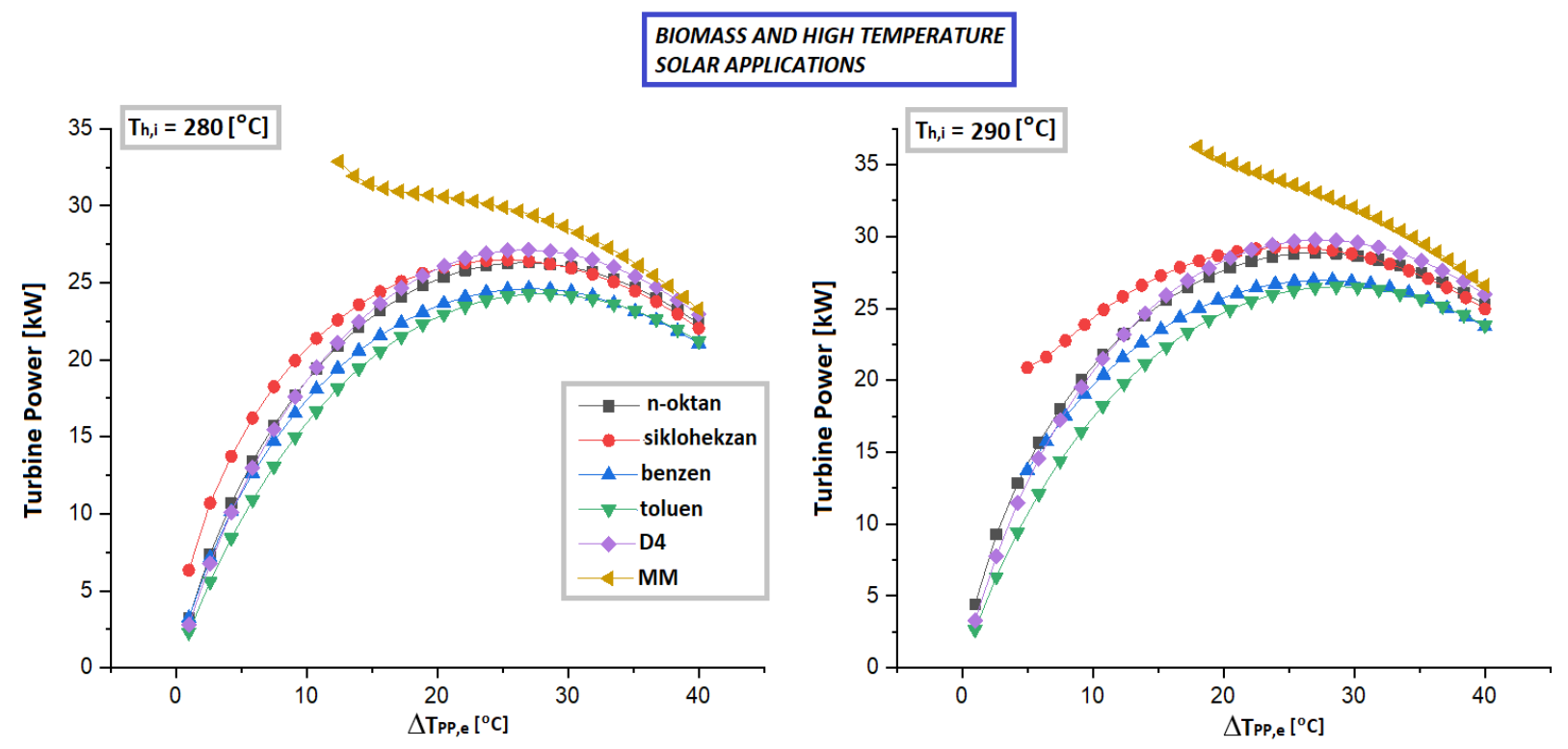

Figure 6. Effect of $\Delta \mathrm{T}_{\mathrm{PP}, \mathrm{e}}$ change on turbine power for 280 and $290{ }^{\circ} \mathrm{C}$ heat source temperatures in ORC's biomass and high temperature solar applications.

Table 6. Determination of optimum $\Delta \mathrm{T}_{\mathrm{PP}, \mathrm{e}}$ value for different fluids under different heat source temperatures for high temperature ORC applications.

\begin{tabular}{|c|c|c|c|c|c|c|}
\hline $\mathrm{T}_{\mathrm{h}, \mathrm{i}}$ & \multicolumn{7}{|c|}{ Optimum $\Delta \mathbf{T}_{\mathbf{P P}, \mathbf{e}}\left({ }^{\circ} \mathbf{C}\right)$} \\
\hline & n-octane & siklohekzan & benzen & toluen & MM & D4 \\
\hline $250^{\circ} \mathrm{C}$ & 23,96 & 23,96 & 25,17 & 25,17 & 21,67 & 23,96 \\
\hline $260^{\circ} \mathrm{C}$ & 25,17 & 23,96 & 26,38 & 26,38 & 21,56 & 25,17 \\
\hline $270{ }^{\circ} \mathrm{C}$ & 25,38 & 25,38 & 27 & 27 & 21,25 & 25,38 \\
\hline $280^{\circ} \mathrm{C}$ & 27 & 25,38 & 27 & 28,63 & 12,5 & 27 \\
\hline $290^{\circ} \mathrm{C}$ & 27 & 25,42 & 26,88 & 28,63 & 18 & 27 \\
\hline
\end{tabular}

\section{REFERENCES}

[1] S. Y. Wu, S. M. Zhou, and L. Xiao, "The determination and matching analysis of pinch point temperature difference in evaporator and condenser of organic rankine cycle for mixed working fluid," Int. J. Green Energy, vol. 13, no. 5, pp. 470-480, 2016, doi: 10.1080/15435075.2014.966371.

[2] H. Yu, X. Feng, and Y. Wang, "A new pinch based method for simultaneous selection of working fluid and operating conditions in an ORC (Organic Rankine Cycle) recovering waste heat," Energy, vol. 90, pp. 3646, 2015, doi: 10.1016/j.energy.2015.02.059.

[3] X. Liu, Y. Zhang, and J. Shen, "System performance optimization of ORC-based geo-plant with R245fa under different geothermal water inlet temperatures," Geothermics, vol. 66, pp. 134-142, 2017, doi: 10.1016/j.geothermics.2016.12.004.

[4] Ö. Kaşka, O. Bor, and N. Tokgöz, "Energy and exergy analysis of an organic rankine-brayton combined cycle," J. Fac. Eng. Archit. Gazi Univ., vol. 33, no. 4, pp. 1201-1213, 2018, doi: 10.17341/gazimmfd.416420.

[5] J. Sun, Q. Liu, and Y. Duan, "Effects of evaporator pinch point temperature difference on thermo- economic performance of geothermal organic Rankine cycle systems," Geothermics, vol. 75, no. February, pp. 249-258, 2018 , doi: 10.1016/j.geothermics.2018.06.001.

[6] A. H. Bademlioglu, R. Yamankaradeniz, and O. Kaynakli, "Exergy analysis of the organic rankine cycle based on the pinch point temperature difference," J. Therm. Eng., vol. 5, no. 3, pp. 157-165, 2019, doi: 10.18186/THERMAL.540149.

[7] J. Wang, M. Diao, and K. Yue, “Optimization on pinch point temperature difference of ORC system based on AHP-Entropy method," Energy, vol. 141, pp. 97-107, 2017, doi: 10.1016/j.energy.2017.09.052.

[8] J. Sarkar, "Generalized pinch point design method of subcritical-supercritical organic Rankine cycle for maximum heat recovery," Energy, vol. 143, pp. 141150, 2018, doi: 10.1016/j.energy.2017.10.057.

[9] M. Jankowski, A. Borsukiewicz, K. SzopikDepczyńska, and G. Ioppolo, "Determination of an optimal pinch point temperature difference interval in ORC power plant using multi-objective approach," J. Clean. Prod., vol. 217, pp. 798-807, 2019, doi: 10.1016/j.jclepro.2019.01.250.

[10] M. Imran, B. S. Park, H. J. Kim, D. H. Lee, M. Usman, and M. Heo, "Thermo-economic optimization of Regenerative Organic Rankine Cycle for waste heat 
recovery applications," Energy Convers. Manag., vol. 87, pp. 107-118, 2014, doi: 10.1016/j.enconman.2014.06.091.

[11] S. Bian, T. Wu, and J. F. Yang, "Parametric optimization of organic rankine cycle by genetic algorithm," Appl. Mech. Mater., vol. 672-674, pp. 741-745, 2014, doi: 10.4028/www.scientific.net/AMM.672-674.741.

[12] R. Long, Y. J. Bao, X. M. Huang, and W. Liu, "Exergy analysis and working fluid selection of organic Rankine cycle for low grade waste heat recovery," Energy, vol. 73, pp. 475-483, 2014, doi: 10.1016/j.energy.2014.06.040.

[13] C. G. Gutiérrez-Arriaga, F. Abdelhady, H. S. Bamufleh, M. Serna-González, M. M. El-Halwagi, and J. M. Ponce-Ortega, "Industrial waste heat recovery and cogeneration involving organic Rankine cycles," Clean Technol. Environ. Policy, vol. 17, no. 3, pp. 767779, 2015, doi: 10.1007/s10098-014-0833-5.

[14] Z. Han, Y. Yu, and Y. Ye, "Selection of working fluids for solar thermal power generation with organic rankine cycles system based on genetic algorithm," ICMREE 2013 - Proc. 2013 Int. Conf. Mater. Renew. Energy Environ., vol. 1, pp. 102-106, 2013, doi: 10.1109/ICMREE.2013.6893624.

[15] L. Pierobon, M. Rokni, U. Larsen, and F. Haglind, "Thermodynamic analysis of an integrated gasification solid oxide fuel cell plant combined with an organic Rankine cycle," Renew. Energy, vol. 60, pp. 226-234, 2013, doi: 10.1016/j.renene.2013.05.021.

[16] R. Agromayor and L. O. Nord, "Fluid selection and thermodynamic optimization of organic Rankine cycles for waste heat recovery applications," Energy Procedia, vol. 129, pp. 527-534, 2017, doi: 10.1016/j.egypro.2017.09.180.

[17] J. G. Andreasen, U. Larsen, T. Knudsen, L. Pierobon, and F. Haglind, "Selection and optimization of pure and mixed working fluids for low grade heat utilization using organic rankine cycles," Energy, vol. 73, pp. 204-213, 2014, doi: 10.1016/j.energy.2014.06.012.

[18] D. Fiaschi, A. Lifshitz, G. Manfrida, and D. Tempesti, "An innovative ORC power plant layout for heat and power generation from medium- to low-temperature geothermal resources," Energy Convers. Manag., vol. 88, pp. 883-893, 2014, doi: 10.1016/j.enconman.2014.08.058.

[19] Z. Kai, Z. Mi, W. Yabo, S. Zhili, L. Shengchun, and N. Jinghong, "Parametric Optimization of Low Temperature ORC System,” Energy Procedia, vol. 75, pp. 1596-1602, 2015, doi: 10.1016/j.egypro.2015.07.374.
[20] G. Li, "Organic Rankine cycle performance evaluation and thermoeconomic assessment with various applications part I: Energy and exergy performance evaluation," Renewable and Sustainable Energy Reviews, 53, pp. 477-499, 2016, doi: 10.1016/j.rser.2015.08.066.

[21] J. M. Calm and G. C. Hourahan, "Refrigerant data update," HPAC Heating, Piping, AirConditioning Eng., vol. 79, no. 1, pp. 50-64, 2007.

[22] T. Ho, S. S. Mao, and R. Greif, "Comparison of the Organic Flash Cycle (OFC) to other advanced vapor cycles for intermediate and high temperature waste heat reclamation and solar thermal energy," Energy, vol. 42, no. $1, \quad$ pp. 213-223, 2012, doi: 10.1016/j.energy.2012.03.067.

\section{NOMENCLATURE}

$\Delta \mathrm{T}_{\mathrm{PP}, \mathrm{e}}$ : Evaporator pinch point temperature difference

$\Delta \mathrm{T}_{\mathrm{PP}, \mathrm{c}}$ : Condenser pinch point temperature difference

Wp: Pump Work

Wt: Turbine Work

Wnet: Net Work

Qe : Evaporator heat load

Qc : Condenser heat load

$\mathrm{i}_{\mathrm{p}}$ : Pump irreversibility

$\mathrm{i}_{\mathrm{e}}$ : Evaporator irreversibility

$\mathrm{i}_{\mathrm{t}}$ : Turbine irreversibility

$\mathrm{i}_{c}$ : Condenser irreversibility

$\mathrm{i}_{\text {total }}$ : Total irreversibility

Th: Average heat source temperature

Tc: Average coling water temperature

Th,i: Heat source inlet temperature

Th,o: Heat source output temperature

Tc,i: Cooling water inlet temperature

Tc,o: Cooling water output temperature

$\eta_{\text {th }} \quad:$ Thermal efficiency

$\eta_{\text {II }} \quad$ : Exergy efficiency

$\eta_{\mathrm{p}} \quad$ : Pump isentropic efficiency

$\eta_{\mathrm{t}} \quad$ : Turbine isentropic efficiency 